\title{
Clinical Implications and Histopathological Correlation of Cervical Lesions Found in Cervico-Vaginal Smears
}

\author{
Dr. Pallavi BR ${ }^{1 *}$, Dr. Hilda Fernandes ${ }^{2}$
}

${ }^{1}$ Department of Pathology, Father Muller Medical College, Mangalore, Karnataka, India

${ }^{2}$ Professor, Department of pathology, Father Muller Medical College, Mangalore, Karnataka, India

\author{
DOI: $\underline{10.36348 / \mathrm{sjpm} .2020 . v 05 \mathrm{i} 02.004}$ \\ | Received: 03.02.2020 | Accepted: 11.02.2020 | Published: 14.02.2020 \\ *Corresponding author: Pallavi BR
}

\section{Abstract}

Papanicolaou (PAP) smear is a cyto-diagnostic technique, which is a simple, safe, non- invasive and effective method for detection of pre-cancerous and non- cancerous changes in cervix as well as vagina. Clinical follow up of reported abnormal cases was done by revisiting the records or by following it up with histopathological specimens of the same patient received in our department and cytology-histopathological correlation was done. A total of 2624 PAP smears were analysed during the study period. 51 smears had abnormal PAP findings, out of which 44 cases had histopathology correlation. The present study encountered that cervical cytology is more sensitive in diagnosing glandular malignancy than squamous cell abnormalities.

Key words: Papanicolaou smear, malignancy of cervix, squamous cell carcinoma, atypical glandular cells, endometroid carcinoma, cervical cytology.

\footnotetext{
Copyright @ 2020: This is an open-access article distributed under the terms of the Creative Commons Attribution license which permits unrestricted use, distribution, and reproduction in any medium for non-commercial use (NonCommercial, or CC-BY-NC) provided the original author and sources are credited.
}

\section{INTRODUCTION}

Cervical cancer is the second most common cancer worldwide next to breast cancer [1]. According to global report of WHO 2014, almost 2, 66,000 women died in the year 2012 from cervical cancer [2]. Cervical cytology is a widely used screening tool for cervical cancer [3]. The main goal of cancer screening is to diagnose and treat in the pre-invasive stage make the disease ideal for screening procedure [4].

Papanicolaou (PAP) test is a cyto-diagnostic technique, named after George Papanicolaou, who introduced it as cancer screening tool in the year 1943. It is the simple, safe, non- invasive and effective method for detection of pre-cancerous and noncancerous changes in cervix as well as vagina [5]. The mortality and morbidity associated with carcinoma cervix can be controlled to a greater extent by this method $[6,7]$.

The aim of this study was to find correlation of cytology of PAP smear and histopathology in detecting the premalignant/ malignant lesion of the cervix.

\section{MATERIALS AND METHODS}

This study was done on all abnormal PAP smears received in department of cytology in the given time period. Initial parameters like age and clinical presentation if available were noted. These cases were further classified into squamous cell and glandular cell abnormalities based on the Bethesda system of reporting cervical cytology. Clinical follow of reported abnormal cases was done by revisiting the records or by following it up with histopathological specimens of the same patient received in our department and cyto-histo correlation was done.

\section{RESULTS}

A total of 2624 PAP smears were received in the department of cytology during the study period. Total 51 smears had abnormal PAP findings, out of which 44 cases had histopathology correlation.

\section{Age distribution}

The mean age of the patient was 51.36+/10.01 years (range 29 to 74 years). Highest number of abnormal PAP smears was between 41-50 years $(43.18 \%)$. 


\section{Clinical presentation}

Most common presentation in patients with abnormal findings was post menopausal bleeding
$31.8 \% \quad(n=14)$. Table 1 shows various clinical presentations.

Table-1: Clinical presentation of cases

\begin{tabular}{|l|c|}
\hline \multicolumn{1}{|c|}{ Clinical presentation } & Number of cases \\
\hline Post menopausal bleeding & $14(31.8 \%)$ \\
\hline Menstural abnormalities (menorrhagia/ polymenorrhoea/ dysfunctional uterine bleeding) & 8 \\
\hline Non specific symptoms (pain abdomen/ mass per abdomen) & 7 \\
\hline Routine screening & 5 \\
\hline White discharge per vagina & 5 \\
\hline Cervical growth & 2 \\
\hline Follow up in cases of carcinoma cervix / endometrium & 2 \\
\hline Post coital bleeding & 1 \\
\hline
\end{tabular}

\section{Distribution of cases}

Out of 2624 cases received, 94.9\% $(n=2492)$ were negative for intraepithelial lesions / Malignancy (NILM), 3.8\% ( $\mathrm{n}=81)$ were unsatisfactory and $1.9 \%$ $(\mathrm{n}=51)$ had abnormal findings (Table 2).

Table-2: Distribution of cases

\begin{tabular}{|l|c|}
\hline \multicolumn{1}{|c|}{ Findings of cytology } & Number of cases \\
\hline NILM & $94.9 \%(\mathrm{n}=2492)$ \\
\hline Unsatisfactory & $3.8 \%(\mathrm{n}=81)$ \\
\hline Abnormal findings & $1.9 \%(\mathrm{n}=51)$ \\
\hline Total & $\mathbf{2 6 2 4}$ \\
\hline
\end{tabular}

Out of 51 cases wih abnormal cytology findings, 44 cases had histopathological follow up. In histopathology 30 cases were reported as squamous abnormalities and 14 cases as glandular abnormalities.

\section{Squamous lesions in cytology}

Out of 30 cases of squamous cells abnormalities, majority were atypical squamous cells of undetermined significance (ASCUS) followed by squamous cell carcinoma (SCC), High grade squamous intraepithelial lesion (HSIL) and atypical squamous cell- cannot exclude HSIL (ASC-H). (Table 3)

Table-3: Squamous cell abnormalities in cytology

\begin{tabular}{|l|c|}
\hline Cytology diagnosis & Number of cases \\
\hline Atypical squamous cell of undetermined significance & $40 \%(\mathrm{n}=12)$ \\
\hline Squamous cell carcinoma & $26.6 \%(\mathrm{n}=8)$ \\
\hline Atypical squamous cell- cannot exclude HSIL & $16.6 \%(\mathrm{n}=5)$ \\
\hline High grade squamous intraepithelial lesion & $16.6 \%(\mathrm{n}=5)$ \\
\hline Total & $\mathbf{3 0}$ \\
\hline
\end{tabular}

\section{Cytology- Histopathology Correlation in Squamous} cell abnormalities

All 30cases were available for histopathological correlation (Table 4). All the cases reported in cytology as ASCUS showed reactive changes of chronic cervicitis in histopathology and 3 cases of ASC-H also showed features of chronic cervicitis.

Table-4: Correlating cases in squamous cell lesions

\begin{tabular}{|l|c|c|}
\hline Cytology diagnosis & Histopathology diagnosis & Number of correlating cases \\
\hline ASC-US & Chronic cervicitis & 12 \\
\hline ASC-H & HSIL-1, SCC-1 & 2 \\
\hline HSIL & SCC & 4 \\
\hline SCC & SCC & 8 \\
\hline & & Total $=26$ \\
\hline
\end{tabular}

PAP smears for diagnosis of squamous lesions had accuracy of $86.6 \%$, sensitivity of $78.8 \%$ and specificity of $63.6 \%$.

\section{Glandular lesions}

14 cases of glandular abnormalities were reported, among these majority of them were atypical glandular cells (AGC) not otherwise specified (AGCNOS) followed by AGC favouring neoplastic and AGC of endometrial origin. (Table 5) 
Table-5: Glandular cell abnormalities in cytology

\begin{tabular}{|l|c|}
\hline Cytology diagnosis & Number of cases \\
\hline AGC-NOS & $64.28 \%(\mathrm{n}=9)$ \\
\hline AGC favouring neoplastic & $28.57 \%(\mathrm{n}=4)$ \\
\hline AGC of endometrial origin & $7.14 \%(\mathrm{n}=1)$ \\
\hline Total & $\mathbf{1 4}$ \\
\hline
\end{tabular}

\section{Cytology-Histopathology correlation in glandular lesions}

Out of 14 cases of glandular lesions, 7 correlated well with histopathology (Table 6).

Table-6: Correlating cases in glandular lesions

\begin{tabular}{|l|c|c|l|c|}
\hline \multirow{2}{*}{ Cytological diagnosis } & \multicolumn{2}{|c|}{ Cervix } & \multicolumn{2}{c|}{ Endometrium } \\
\cline { 2 - 6 } & Histopathology & No of cases & Histopathology & No of cases \\
\hline AGC-NOS $(n=9)$ & Adenocarcinoma & 1 & Endometrioid adenocarcinoma & 2 \\
\hline AGC EM $(n=1)$ & - & & Endometrioid adenocarcinoma & 1 \\
\hline AGC favouring neoplasm $(n=4)$ & & & Endometrioid adenocarcinoma & 3 \\
\hline
\end{tabular}

In other 7 smears, 6 cases of AGC- NOS were diagnosed as chronic cervicitis and in 1 case histopathological features were of squamous cell carcinoma.

In case of glandular lesions, PAP smears had accuracy of $71.9 \%$, sensitivity of $100 \%$ and specificity of $81.1 \%$.

\section{Follow- up of abnormal pap smears}

Out of 12 cases of ASCUS, 66.6\% ( $n=7)$ underwent total abdominal hysterectomy with bilateral salpingo-oophorectomy (TAH+BSO) and repeat PAP smear was done in 2 cases. Cervical biopay was taken in 3 out of 5 cases of ASC-H and in other 2 cases, TAH+ BSO was done. Majority of patients with SIL and SCC, $84.6 \%(n=11)$ underwent colposcopic guided cervical biopsy and followed by TAH+BSO. Surgical management was preferred in most of glandular lesions. 7 cases $(50 \%)$ underwent TAH+ BSO, biopsy in 5 cases $(35.7 \%)$. Follow up was not available in other 2 cases.

\section{DISCUSSION}

Majority of the patients were in the age group of 41- 50 years (43.18\%). Ranabhat et al. [8] studied on 880 Pap smears and found that abnormal epithelial lesions are commonly seen above 40 years which is also seen in our study. In cytology, most of the smears were negative for malignancy $(94.9 \%)$ which is similar to study done by Atla BL et al. [9]. Squamous cell abnormalities constituted majority of the abnormal smears (68.18\%), of which ASC-US is most common. A study done by Sosic et al. [10] had similar findings in their study. Overall statistics analysis for epithelial cell abnormalities had accuracy of $86.6 \%$, sensitivity of $78.8 \%$ and specificity of $63.6 \%$. Nasreen et al. [11] and Jain et al. [12] had diagnostic accuracy of $79.09 \%$ and $73.2 \%$.

\section{CONCLUSION}

Pap smear is simple and effective diagnostic tool for early detection of premalignant and malignant cervical lesions. The cytological and histopathological findings correlated well with histopathology in majority of cases. The present study encountered that cervical cytology is more sensitive in diagnosing glandular malignancy than squamous cell abnormalities.

\section{REFERENCES}

1. Naik, R., Minj, M.M., Panda, R., Satpathi, S., Behera, P.K., Panda, K.M. (2015). Cytohistological correlation and accuracy of the pap smear test in diagnosis of cervical lesions: a hospital based cross- sectional study from Odisha, India. MS. 3(3): 242-9.

2. Comprehensive Cervical Cancer Control A guide to essential practice. (2014). Second edition. World Health Organization 2014. Accessed on 15-082015 from URL: http://apps.who.int/iris/bitstream/10665/144785/ 1/9789241548953_eng.pdf.

3. Dhakal, R., Makaju, R., Sharma, S., Bhandari, S., Shrestha, S., Bastakoti, R. (2016). Correlation of cervical Pap smear with Biopsy in the lesion of cervix. Kathmandu Univ Med J. 55(3): 254-7.

4. Patil, S., Patil, A., Solanke, P. (2015). Cytological screening for early diagnosis of cervical intraepithelial neoplasia (CIN) and early carcinoma of cervix. Int J Sci Res Publ, 5:1-6.

5. Joshi, C., Kujur, P., Thakur, N. (2015). Correlation of Pap smear and Colposcopy in Relation to Histopathological Findings in Detection of Premalignant Lesions of Cervix in A Tertiary Care Centre. Int J Sci Stud. 3(8):55-60.

6. Sivanessartnam, V. (1999). Pathology and management of CIN lesion of the cervix. In: Ratnam SS, Rao KB,Arulkumaran S. eds. Obstetrics and gynecology for post graduate. $2^{\text {nd }}$ ed. New Delhi: Orient Longman, 364-79.

7. Singh, P., Ilancheran, A. (1989). The 'Pap' or 
cervical smear and the role of colposcopy in screening for carcinoma of the cervix. Singapore Med J. 30(3):302-5.

8. Ranabhat, S.K., Shrestha, R., Tiwari, M. (2011). Analysis of abnormal epithelial lesions in cervical pap smears in mid-western Nepal. $J$ of Pathol of Nepal, 1:30-3.

9. Atla, B.L., Uma, P., Shamili, M., Kumar, S.S.(2015). Cytological patterns of cervical pap smears with histopathological correlation. Int J Res Med Sci. 3(8):1911-6.

10. Sosic, G.M., Babic, G., Dimitrijevic, A., Mitrovic,
S., Varjacic, M. (2014). Correlation between cervical cytology and Histopathological Cervical Biopsy findings according to the Bethesda system. Ser J Exp Clin Res, 15(4): 205-216.

11. Nasreen, M. (2013). Evaluation of Conventional Pap Test for Cervical Intraepithelial lesions and Cancer in a Tertiary Hospital of Bangladesh. Chattagram Maa-O-Shishu Hospital Medical College, 12(2).

12. Jain, V., Vyas, A.S. (2010). Cervical NeoplasiaCyto- Histological Correlation (Bethesda System) A Study of 276 Cases. J Cytol Histo, 1:106. 